\title{
PENERAPAN JUST IN TIME UNTUK EFISENSI BIAYA PERSEDIAAN
}

\section{El Bethree Jeremya Janson $\mathbf{B}^{1}$ I Nyoman Nurcaya ${ }^{2}$}

\author{
${ }^{1,2}$ Fakultas Ekonomi dan Bisnis Universitas Udayana (Unud), Bali,Indonesia \\ e-mail: bethreejeremya3001@gmail.com
}

\begin{abstract}
ABSTRAK
Just In Time adalah suatu sistem yang dirancang untuk mendapatkan kualitas yang baik, menekan biaya, dan mencapai waktu dan biaya seefisien mungkin dengan menghilangkan pemborosan yang ada. Penelitian ini dilakukan di Pizza Hut Delivery Kerobokan, ditujukan untuk mengetahui serta menganalisis penerapan Just In Time dalam meningkatkan efisiensi biaya persediaan. Metode pengumpulan data dilakukan dengan melakukan observasi pada objek yang diteliti. Teknik analisis data yang digunakan adalah teknik analisis secara deskriptif kuantitatif. Hasil penelitian ini menunjukkan bahwa sistem pembelian secara tradisional yang diterapkan pada tahun 2016 masih belum efektif, karena masih menggunakan sistem secara tradisonal yang menyebabkan pemborosanpemborosan. Perusahaan Pizza Hut Delivery sebaiknya melakukan penerapan sistem pembelian secara Just In Time, mengadakan kesepakatan dengan pemasok mengenai kualitas, jumlah, dan waktu pengiriman bahan baku dengan adanya kesepakatan dengan pemasok perusahaan dapat meminimalisir biaya penyimpanan dan pemesanan.
\end{abstract}

Kata kunci: just in time, efisiensi biaya, persediaan

\begin{abstract}
Just In Time is a system designed to get good quality, reduce costs, and achieve time and cost as efficiently as possible by eliminating the waste. This research was conducted at Pizza Hut Delivery Kerobokan, aimed at knowing and analyzing Just In Time implementation in improving inventory cost efficiency. Data collection method is done by observing the object under study. Data analysis techniques used are descriptive quantitative analysis techniques. The results of this study indicate that the traditional purchasing system that was implemented in 2016 is still not effective, because it still uses the traditional system which causes waste. Pizza Hut Delivery companies should implement the Just In Time purchase system, enter into agreements with suppliers regarding the quality, quantity and time of raw material delivery with an agreement with the supplier of the company to minimize storage and ordering costs.
\end{abstract}

Keywords: just in time, cost efficiency, inventory 


\section{PENDAHULUAN}

Perkembangan industri di Indonesia yang semakin maju dan cepat memaksa perusahaan-perusahaan harus memiliki strategi yang ampuh dan tepat sasaran. Hal tersebut bertujuan agar terpenuhinya kebutuhan konsumen yang semakin banyak, bervariasi, dan beragam, sehingga menuntut produk dengan pelayanan yang cepat, tepat dan bermanfaat. Salah satu cara yang bisa digunakan dalam pelayanan proses produksi cepat dan tepat itu adalah dengan meningkatkan kualitas produk yang diproduksi serta menekan biaya yang dikeluarkan sehingga proses produksi berjalan dengan lancar dan permintaan konsumen dapat terpenuhi cepat serta tepat waktu. Bagi para pelaku ekonomi dalam menghadapi persaingan tersebut dapat menggunakan seluruh potensi yang ada secara efektif dan efisien (Putra dan Idayati, 2014:2). Perkembangan teknologi manufaktur yang semakin maju menghasilkan sebuah sistem yang dikenal dengan sistem Just In Time. Sistem Just In Time adalah sebuah filosofi pemecahan masalah secara berkelanjutan dan memaksa dengan cara menghilangkan pemborosan yang dianggap tidak memilki nilai tambah (Heizer dan Render, 2004:257).

Menurut penelitian Dalci dan Tanis (2006) saat ini sistem Just In Time sudah terkenal di seluruh dunia. Alasan mengapa sistem yang begitu populer saat ini adalah hasil dari keuntungan yang direalisasikan oleh perusahaan manufaktur. Chang dan Chou (2012) World Class Manufacturing adalah filosofi manajemen yang menekankan pada pemenuhan kebutuhan dan harapan pelanggan eksternal dan internal dan pentingnya melakukan sesuatu yang benar untuk masyarakat pasar dunia. Salah satu teknik produksi kelas dunia adalah Just In Time. Setiap 
perusahaan bertujuan untuk memaksimalkan laba (Diaz dan Retnani, 2015:2). Oleh karena itu, untuk mencapai laba yang maksimum diperlukan suatu sistem atau metode agar kemampuan yang dimiliki suatu perusahaan dapat mencapai tujuan tersebut. Dengan menerapkan sistem Just In Time ini maka diharapkan perusahaan dalam proses produksinya akan memiliki biaya yang rendah, harga jual yang murah, kualitas yang baik, dan kemampuan ketepatan waktu pengiriman kepada pelanggan (Putra dan Idayati, 2014:2).

Biasanya, proses Just In Time diimplementasikan dalam organisasi yang mencapai aplikasi Just In Time tertinggi. (Wagner dan Camargos, 2009). Perusahaan harus mampu menciptakan proses produksi yang efisien untuk dapat menekan biaya produksi. Proses produksi yang efisien akan tercapai bila perusahaan dapat mengurangi kegiatan-kegiatan yang tidak memberikan nilai tambah (non value added activities). Salah satu cara yang terbaik bagi perusahaan agar dapat mengeliminasi non value added activities guna mencapai suatu proses yang efisien, yaitu dengan menerapkan proses produksi dengan sistem penyimpanan bahan baku dengan metode Just In Time (Suwardi, 2009). Sistem ini merupakan suatu filosofi bisnis untuk mengeliminasi pemborosan dengan mengurangi waktu penyimpanan bahan baku dalam suatu proses produksi yang termasuk dalam non value added activities. Sistem Just In Time yang pertama kali diterapkan secara modern pada tahun 1970 di Jepang (Suwardi, 2009). Just In Time menekankan pada sistem operasi yang sederhana dan efisien yang mampu menggunakan secara optimal sumber-sumber daya yang ada dalam industri, seperti modal, peralatan, dan tenaga kerja. 
Penggunaan sumber-sumber daya yang optimal akan menghasilkan keluaran atau output yang mempunyai cost yang relatif rendah. Sistem Just In Time menekankan pada penyederhanaan aktivitas pada lini produksi, hanya aktifitas utama yang menambah nilai produk yang akan dijalankan. Dengan demikian perusahaan akan memiliki keuntungan yang lebih tinggi tanpa mengurangi kualitas dari produk yang dihasilkan. Pada sistem pembelian Just In Time bahan baku yang dibeli tiba pada saat yang diperlukan dan dapat mengurangi tingkat kerusakan bahan baku karena dalam hal ini bahan baku tidak perlu disimpan atau ditumpuk dalam waktu yang lama. Dengan demikian perusahaan yang mampu bertahan di dunia bisnis adalah perusahaan yang mampu menghasilkan produkproduk yang bermutu tinggi dengan harga jual yang bersaing (Nurhidayati, 2017).

Tujuan implementasi Just In Time adalah memproduksi produk yang hanya dibutuhkan konsumen pada waktu yang tepat pada tingkat kualitas yang diinginkan. Di Indonesia, implementasi Just In Time saat ini telah digunakan oleh banyak perusahaan, terutama pada perusahaan besar. Perusahaan menyadari bahwa untuk mendapatkan profit di era persaingan ini haruslah bekerja seefisien mungkin. Dukungan Just In Time terhadap manajemen kualitas sangat penting karena Just In Time manufacturing telah menjadi strategi utama untuk keunggulan bersaing (Yuniawan dan Sudharmono, 2005)

Penelitian terdahulu yang telah dilakukan oleh Veselko dan Jakomin (2006) menghasilkan kesimpulan konsep Just In Time merupakan salah satu konsep terpenting untuk operasi bisnis kontemporer, yang mendukung usaha terus menerus untuk memotong biaya produksi, atau penghitungan diferensiasi 
produksi, dan mencapai kepuasan pelanggan. Berdasarkan penelitian Putra dan Idayati (2014), perusahaan manufaktur saat ini masih menggunakan metode yang hanya berdasarkan pengalaman di periode sebelumnya, sehingga mengalami pemborosan seperti di dalam gudang terdapat banyak persediaan bahan baku. Maka akan terjadi penambahan biaya penyimpanan, sehingga akibatnya perusahaan akan menanggung biaya persediaan bahan baku yang cukup tinggi dan tidak terdapat efisiensi biaya persediaan. Penelitian oleh Sari et al. (2014) memiliki kesimpulan lain, dengan menggunakan sistem Just In Time perusahaan dapat mengurangi biaya bahan baku langsung, biaya tenaga kerja langsung, biaya pemakaian mesin langsung, dan biaya produksi. Menurut penelitian dari Abduh dan Siahaan (2007), sistem manajemen persediaan yang mengimplementasi konsep Just In Time dengan sistem Kanban (sistem informasi yang secara serasi mengendalikan produksi produk yang dalam jumlah yang diperlukan pada waktu yang diperlukan dalam setiap proses) sebagai alat pengendali persediaan, berupa stok produk jadi, komponen dan bahan baku, merupakan sistem yang akurat dalam mengendalikan biaya-biaya persediaan, yaitu biaya persiapan-pemesanan, biaya penyediaan-penyimpanan, biaya kehabisan stok, dan biaya yang terkait dengan kapasitas.

Penelitian dari Johan (2008) menyimpulkan ada hal yang perlu dicatat mengenai dengan penerapan system Just In Time, yaitu filosofi Just In Time didasarkan pada tiga prinsip utama, yaitu meminimalkan pemborosan dalam segala bentuknya, terus-menerus meningkatkan proses dan sistem, dan menjaga hubungan diantara semua pekerja, sehingga bisa menghasilkan keunggulan dalam 
hal penurunan biaya dan respon yang cepat terhadap konsumen. Penelitian yang dilakukan Azhar (2009) menyatakan sistem Just In Time merupakan sistem produksi yang komprehensif dari sistem persediaan dimana bahan baku dan persediaan dibeli sesuai dengan kebutuhan produksi. Just In Time dapat diterapkan pada semua tingkatan bisnis seperti pembelian bahan baku, proses produksi dan pendistribusian produk kepada pelanggan. Meskipun demikian Just In Time bukan berarti menekankan pada aspek Zero Inventory Production (ZIP). Inti dari konsep Just In Time adalah program pengurangan jumlah persediaan yang dibutuhkan dalam waktu yang tepat.

Pizza Hut Delivery (PHD) merupakan sebuah perusahaan yang bergerak di bidang industri makanan dalam kemasan yang telah berdiri sejak tahun 2007 dengan pelayanan pesan antar (delivery) dan pesan bawa (take away). Sehingga Pizza Hut Delivery (PHD) hanya memerlukan tempat untuk membuat produk (kitchen) dan counter hanya untuk melayani pesan bawa. Produk yang ditawarkan oleh Pizza Hut Delivery (PHD) adalah Pizza yaitu yang memiliki berbagai varian rasa dan ukuran. Berdasarkan observasi awal di Pizza Hut Delivery (PHD), diketahui bahwa perusahaan makanan tersebut masih menggunakan sistem secara tradisional. Sistem secara tradisional yang dimaksud adalah sistem yang hanya memproduksi barang yang akan dijual saja tanpa memberlakukan perhitungan terlebih dahulu dan sistem tradisional ini dapat menyebabkan pemborosanpemborosan yang terjadi di dalam sistem produksi. Pembelian bahan baku pembuatan pizza datang di hari yang sama tiap minggunya dan tepat waktu. Mengingat adanya metode Just In Time yang dapat meminimumkan efisiensi 
biaya pemesanan dan penyimpanan dalam perusahaan, maka dilakukan penelitian untuk membandingkan cara perhitungan tradisional yang saat ini diterapkan oleh Pizza Hut Delivery (PHD) dalam pemesanan dan penyimpanan dengan metode Just In Time.

Seperti yang diketahui Pizza Hut Delivery (PHD) menggunakan sistem Made To Order, oleh karena itu Pizza Hut Delivery (PHD) harus mempunyai strategi yang tepat agar dalam merencanakan persediaan bahan baku perusahaan dapat memenuhi rencana produksi secara efektif dan efisien. Dengan sistem Just In Time diharapkan pemenuhan kebutuhan produksi dapat dilakukan secara cepat dan tepat serta penentuan biaya dapat ditetapkan seoptimal mungkin. Pemilihan ini didasarkan pada kenyataan bahwa perusahaan makanan di Indonesia merupakan salah satu industri yang cukup berkembang dan banyak dinikmati dan dikonsumsi oleh khalayak ramai, serta salah satu sektor penting dalam perekonomian Indonesia.

Tujuan dari penelitian ini adalah untuk menganalisis penerapan Just In Time untuk efisiensi biaya persediaan pada perusahaan Pizza Hut Delivery (PHD) serta untuk melihat apakah Just In Time dapat meningkatkan efisiensi biaya persediaan pada perusahaan Pizza Hut Delivery (PHD). Penelitian ini tidak hanya dapat memberikan manfaat bagi penulis, namun juga memberikan manfaat bagi pihak pihak lain yang terkait langsung maupun tidak langsung. Secara teoritis, penelitian ini diharapkan dapat dijadikan tambahan pengetahuan atau bahan kajian dan wawasan untuk mendukung penelitian selanjutnya yang berkaitan dengan penerapan sistem Just In Time yang dilaksanakan perusahaan. Secara praktis, 
penelitian ini diharapkan mampu menambah pengetahuan dan pemahaman mahasiswa mengenai penerapan teori yang telah diperoleh dalam perkuliahan terutama mengenai penerapan teori tersebut pada perusahaan. Bagi perusahaan, hasil yang diperoleh dalam penelitian ini dapat dijadikan alternatif bagi perusahaan untuk melaksanakan sistem Just In Time untuk pengukuran kinerja yang difokuskan pada ketepatan waktu, ketepatan kualitas dan ketepatan jumlah barang. Bagi pihak lain, hasil penelitian ini dapat digunakan untuk menambah wawasan pengetahuan pembaca dan sekitarnya.

Menurut Sjahrial dan Purba (2012:115), sistem Just In Time Manufacturing adalah suatu sistem berdasarkan tarikan permintaan yang membutuhkan barang untuk ditarik melalui sistem permintaan yang ada, bukan didorong kedalam sistem pada waktu tertentu berdasarkan permintaan yang di antisipasi. Salah satu pendekatan untuk mengeliminasi pemborosan dalam perusahaan manufaktur telah muncul yaitu suatu filosofi operasi yang disebut Just In Time. Suatu filosofi operasi manajemen, yaitu sumber daya, termasuk material personel, dan fasilitas yang digunakan dalam keadaan tepat waktu. Just In Time adalah sebuah filosofi pemecahan masalah secara berkelanjutan dan memaksa yang mendukung produksi yang ramping (lean). Produksi yang ramping (lean Production) memasok pelanggan persis sesuai dengan keinginan pelanggan ketika pelanggan menginginkannya, tanpa pemborosan, melalui perbaikan berkelanjutan (Heizer and Render, 2004:258).

Sasaran utama Just In Time adalah meningkatkan produktivitas system produksi atau operasi dengan cara menghilangkan semua macam kegiatan yang 
tidak menambah nilai (pemborosan) bagi suatu produk. Sasaran Just In Time menitikberatkan pada continuos improvement untuk mencapai biaya produksi yang rendah, tingkat produktivitas yang lebih tinggi, kualitas dan realibitas produk yang lebih baik, memperbaiki waktu penyerahan produk akhir dan memperbaiki hubungan kerja antara pelanggan dengan pemasok (Ariani, 2003). Menurut Heizer dan Render (2010), Just In Time menjadi sebuah alat bantu (tools) yang sangat baik bagi perusahaan untuk mengurangi terjadinya waste dan faktor-faktor perubahan yang tidak diinginkan. Definisi Just In Time didefinisikan sebagai sistem manajemen pabrikasi dan persediaan komprehensif di mana bahan baku dan berbagai suku cadang dibeli dan diproduksi pada saat diproduksi dan pada saat Just In Time akan digunakan dalam setiap tahap proses produksi/pabrikasi. (Simamora, 2002:105).

Menurut penelitian Kootanaee et al. (2013) saat ini banyak perusahaan sedang mempelajari dan menerapkan pendekatan Just In Time sebagai respons terhadap lingkungan yang semakin kompetitif. Organisasi Amerika Utara menyadari tekanan yang diberikan pada mereka atas keberhasilan pesaing Jepang mereka dalam memperoleh tingkat produktivitas yang fenomenal. Agar tetap kompetitif dan mengalami kesuksesan ekonomi, perusahaan-perusahaan ini berfokus pada peningkatan produktivitas, meningkatkan kualitas produk mereka dan meningkatkan standar efisiensi dalam produk mereka dan meningkatkan standar efisiensi di dalam perusahaan mereka. Sasaran utama Just In Time adalah meningkatkan produktivitas sistem produksi atau operasi dengan cara menghilangkan semua macam kegiatan yang tidak menambah nilai (pemborosan) 
bagi suatu produk. Sasaran Just In Time menitikberatkan pada continuos improvement untuk mencapai biaya produksi yang rendah, tingkat produktivitas yang lebih tinggi, kualitas dan realibitas produk yang lebih baik, memperbaiki waktu penyerahan produk akhir dan memperbaiki hubungan kerja antara pelanggan dengan pemasok. Menurut Tjahjadi (2001:227) mendefinisikan Just In Time sebagai dengan istilah berhasil menyelesaikan suatu produk atau layanan pada setiap tahap aktivitas produksi dari vendor ke pelanggan tepat pada waktunya untuk penggunaannya dan dengan biaya minimum. Just In Time juga dapat didefinisikan secara umum sebagai strategi atau filosofi panduan yang tujuannya untuk mencari keunggulan manufaktur.

Dalam sistem Just In Time ada beberapa peranan penting yaitu menghasilkan sebuah produk hanya ketika dibutuhkan dan hanya dalam kuantitas yang diminta oleh pelanggan. Menurut Kuncoro (2005:293) berpendapat bahwa Just In Time memiliki beberapa peranan penting diantaranya: (1). Meningkatkan laba, (2). Meningkatkan posisi persaingan perusahaan yang dicapai melalui: (a). Pengendalian biaya, (b). Peningkatan kualitas, (c). Perbaikan kinerja kualitas. Menurut Krismiaji (2011:125) tujuan utama Just In Time adalah untuk menghasilkan produk hanya jika diperlukan dan hanya menghasilkan kuantitas produk sebanyak yang diminta pelanggan. Manfaat utama sistem Just In Time adalah akan mengubah daya telusur biaya, meningkatkan akurasi penentuan cost product, menurunkan kebutuhan alokasi biaya tak langsung, mengubah perilaku dan kepentingan relatif biaya tenaga kerja langsung dan mempengaruhi sistem penentuan cost pesanan dan cost proses. 
Konsep Just In Time menurut Blocher et al. (2002) Sistem Just In Time adalah sistem manajemen produksi dan persediaan yang komprehensif yang membeli atau memproduksi bahan dan bagian hanya sesuai kebutuhan dan tepat pada waktunya untuk digunakan pada setiap tahap proses produksi. Menurut Hilton et al. (2000), konsep Just In Time adalah proses untuk membeli, membuat, dan mengirimkan produk hanya jika dibutuhkan. Hasil penelitian dari Bannock et al. (2003) mengemukakan konsep Just In Time adalah bentuk manajemen produksi, yang berasal dari Jepang, di mana perusahaan tidak mendapatkan persediaan komponen sampai mereka benar-benar dibutuhkan.

Keberhasilan Just In Time tidak terlepas dari peran pemasok, oleh karena itu hubungan antara pemasok dengan pelanggan harus dijaga dengan baik. Heizer dan Render (2004:261) menyatakan kemitraan Just In Time ada ketika pemasok dan pembeli bekerja sama dengan sebuah sasaran bertimbal balik untuk menghilangkan pemborosan dan menekan biaya. Menurut Heizer dan Render (2016:726) 4 sasaran kemitraan Just In Time yaitu: (1). Menghilangkan kegiatan tidak perlu, (2). Menghilangkan persediaan di pabrik, (3). Menghilangkan persediaan in transit, (4). Mendapatkan peningkatan mutu dan andalan melalui komitmen, komunikasi, Just In Time sangat membutuhkan hubungan khusus antara pemasok dengan perusahaan pembeli dimana kedua belah pihak dituntut untuk bekerja sama untuk mencapai keberhasilan bersama dimasa yang akan datang. Adapun karakteristik menurut Tjahjadi (2001:232) hubungan antara pemasok Just In Time dengan perusahaan pembeli meliputi: (1). Kontrak jangka panjang, (2). Meningkatnya akurasi administrasi pesanan, (3). Meningkatnya 
kualitas, (4). Fleksibilitas pesanan, (5). Pengiriman jumlah kecil dengan frekuensi pengiriman yang banyak, (6). Perbaikan berkesinambungan dalam bekerja sama. Perusahaan pembeli harus bisa mencari pemasok terpercaya yang dapat mengirimkan barang berkualitas, dengan jumlah dan waktu yang telah ditentukan.

Penelitian dari Pai et al. (2013) menyatakan ketika perusaaan manufaktur beralih ke pengiriman material secara Just In Time, pemasok harus lebih sering memberikan dengan keandalan atau mutu yang jauh lebih baik. Untuk memenuhi persyaratan yang lebih cermat ini, pemasok harus sering membawa dan menyediakan persediaan tambahan.

Dalam banyak kasus perusahaan pembeli menetapkan jadwal jam pengiriman, bahkan menit pengiriman juga telah ditentukan. Kegagalan pemenuhan jadwal yang dipesan akan berakibat fatal, yaitu berhentinya produksi (Tjahjadi, 2001:229). Dari uraian diatas maka indikator pemasok yang dapat dimunculkan adalah: mendukung hubungan dengan para pemasok, penyerahan barang berkualitas tepat waktu.

Karakteristik merupakan sistem tradisional melakukan aktivitas pembuatan produk berdasarkan ramalan penjualan (sales forecasting) yang diperkirakan akan terjadi pada periode mendatang. Dengan dasar ini, maka bagian produksi akan memiliki jadwal produksi yang sudah pasti. Jika barang yang diproduksi belum dapat didistribusikan ke pasar, maka barang tersebut akan disimpan di gudang. Dalam hal ini bagian pemasaran bertanggung jawab untuk segera memasarkan produk yang telah menumpuk di gudang jumlah banyak. Dengan demikian, sistem tradisional ini mendorong (push) aktivitas penjualan dan pemasaran. Sistem Just 
In Time memiliki karakteristik yang berkebalikan. Dalam sistem ini, perusahaan baru akan melakukan aktivitas produksi hanya jika ada permintaan pasar/pelanggan yang sudah pasti. Jadi aktivitas produksi dalam sistem ini ditarik (pull) oleh permintaan pasar.

Kuantitas Persediaan merupakan salah satu pengaruh sistem Just In Time bagi perusahaan adalah mengurangi kuantitas persediaan secara signifikan. Dalam jumlah yang minimal, persediaan tetap dimiliki oleh perusahaan, terutama persediaan produk jadi yang menunggu proses pengiriman kepada pelanggan atau ke distributor. Jadi kuantitas persediaan dalam sistem Just In Time tetap ada namun jumlahnya sangat sedikit (insignificant). Sistem manufaktur tradisional disebut juga push through system. Dalam sistem ini, perusahaan melakukan proses produksi tanpa memperhatikan struktur dan kondisi permintaan pada saat itu. Oleh karena itu, sistem ini sangat mungkin menghasilkan produk dalam jumlah yang lebih besar dibandingkan dengan permintaannya, sehingga menciptakan persediaan dalam jumlah yang banyak (significant).

Struktur manufaktur, dalam sistem ini manufaktur tradisional, mesin-mesin produksi yang sejenis disatukan dalam sebuah departemen. Dengan demikian, jika perusahaan membuat 2 jenis (produk $\mathrm{X}$ dan produk $\mathrm{Y}$ ) produk melalui 3 jenis mesin (mesin 2, mesin 3 dan mesin 4), maka tahap pertama kedua produk tersebut akan masuk proses di proses departemen 1, tahap kedua sama-sama masuk proses di departemen 2, tahap ketiga sama-sama masuk di departemen 3. Dalam hal ini, kedua produk menggunakan seluruh fasilitas di departemen produksi 1 sampai 3 secara bersama-sama. Implikasinya adalah, pada akhirnya proses perusahaan 
harus mengalokasikan biaya tidak langsung atau biaya pemakaian fasilitas bersama tersebut (penggunaan mesin $\mathrm{X}$, mesin $\mathrm{Y}$, mesin Z).

Just In Time menggunakan struktur sel manufaktur (manufacturing cell). Dengan struktur ini mesin yang diperlukan untuk membuat sebuah produk, dikelompokkan ke dalam sebuah sel manufaktur. Jika perusahaan menghasilkan 2 jenis produk, maka perusahaan tersebut akan menghasilkan 2 sel, sel X khusus untuk membuat produk $\mathrm{X}$ dan sel $\mathrm{Y}$ khusus untuk membuat produk Y. Dengan menggunakan contoh di atas, maka pada sel $\mathrm{X}$ akan terdapat 3 buah mesin, yaitu mesin nomor 2, mesin nomor 3, mesin nomor 4. Sedangkan sel Y juga akan berisi 3 buah mesin yang khusus digunakan untuk membuat produk Y. Sel-sel ini pada dasarnya merupakan pabrik mini, oleh karena itu dengan menggunakan konsep sel seolah-olah ada pabrik dalam pabrik. Kualifikasi tenaga kerja, dalam sistem konvensional, tenaga kerja biasanya berspesialisasi dalam satu bidang keahlian tertentu.

Para karyawan dilatih untuk melaksanakan sebuah pekerjaan khusus, misalnya mengoperasikan sebuah mesin. Dari waktu ke waktu tugas yang dibebankan kepada mereka relatif tidak berubah. Dengan demikian, mereka menjadi tenaga kerja spesialis. Dalam sistem Just In Time, yang menggunakan struktur manufaktur sel, karyawan produksi dituntut untuk mampu mengoperasikan seluruh mesin yang ada dalam sebuah sel. Hal ini dilakukan dalam rangka meningkatkan efisiensi dan menekan biaya. Dengan demikian karyawan tersebut tidak lagi menjadi spesialisasi mesin tertentu, namun menjadi seorang yang memiliki kualifikasi multidiciplinary. Kebijakan kualitas, dalam 
sistem Just In Time, perusahaan memproduksi barang dalam jumlah terbatas, yaitu sebanyak yang diminta oleh pasar/pelanggan dan tidak memiliki kelebihan produksi sama sekali. Oleh karena itu, dalam sistem ini persoalan kualitas merupakan hal yang sangat penting. Kualitas barang yang dihasilkan harus sempurna, dan tidak ada toleransi sama sekali terhadap produk cacat. Kalau sampai ada produk cacat dan sampai ke tangan konsumen, maka hal ini akan merusak reputasi perusahaan, apalagi jika perusahaan tersebut berada dalam industri yang bersaing ketat.

Untuk mewujudkan hal ini, perusahaan harus memiliki komitmen tinggi terhadap kualitas dan menerapkan konsep pengendalian mutu terpadu (total quality control). Tanpa TQC sistem Just In Time tidak akan berjalan dengan baik. Kondisi tersebut tentunya sangat berbeda dengan kondisi yang ada pada sistem tradisional. Dalam sistem tradisional ada sebuah prinsip yang disebut Acceptable Quality Level (AQL). Prinsip tersebut memperbolehkan adanya produk cacat dalam sebuah proses produksi, asalkan jumlahnya tidak melebihi angka persentase yang telah diterapkan sebelumnya. Hal tersebut dimungkinkan karena dalam sistem tradisional jumlah produk yang dihasilkan banyak, sehingga jika ada produk cacat, perusahaan masih memiliki kesempatan untuk menyortirnya agar tidak ikut terbawa sampai ke tangan konsumen.

Sistem pembelian Just In Time mengharuskan adanya sistem penjadwalan pengadaan barang dengan cara sedemikian rupa sehingga dapat dilakukan penyerahan segera untuk memenuhi permintaan atau penggunaan (Supriyono, 2002:67). Pembelian Just In Time adalah pembelian bahan-bahan atau barang 
sedemikian sehingga mereka dikirimkan hanya pada saat dibutuhkan bagi produksi atau penjualan (Hongren, 2008:337).

Dari pengertian tersebut dapat disimpulkan bahwa pembelian Just In Time adalah sistem pembelian penjadwalan pengadaan barang atau bahan yang tepat waktu sehingga dapat dilakukan pengiriman atau penyerahan secara cepat dan tepat untuk memenuhi permintaan. Dalam rangka menerapkan Just In Time, maka kondisi dan proses pembelian harus diatur dengan mempertimbangkan hal-hal berikut: (a). Dekat dengan pemasok, (b). Sedikit pemasok, (c). Pemasok tahu kualitas yang diinginkan perusahaan, (d). Meminimalisasi inspeksi, (e). Eliminasi penggudangan.

Sering kita dengar ungkapan-ungkapan bahwa untuk bisa memperoleh laba yang besar dan untuk mempertahankan eksistensi perusahaan, maka perusahaan harus beroperasi secara efisien. Istilah efisiensi mempunyai arti yang sangat spesifik, biasanya efisiensi sering dikaitkan dengan perbandingan output dan input dimana semakin besar perbandingan ouput atau inputnya maka akan semakin efisiensi suatu usaha. Cara meningkatkan efisiensi biaya yaitu dapat dilakukan melakukan dengan melalui sistem perencanaan yang lebih baik, alat-alat produksi dan berbagai masukan yang tersedia yang lebih baik dengan berhubungan kerja dan kinerja yang lebih baik pula dengan menggunakan kebijakan-kebijakan diberbagai bidang yang tepat.

\section{METODE PENELITIAN}

Lokasi penelitian ini adalah di perusahaan Pizza Hut Delivery (PHD), sebuah perusahaan yang bergerak di bidang industry makanan yang terletak di 
Jalan Raya Kerobokan No. 51, Kerobokan Kelod, Kuta Utara, Kabupaten Badung Badung, Bali. Objek yang digunakan dalam penelitian ini adalah catatan historis mengenai persediaan bahan baku Pizza Hut Delivery (PHD) dan mengenai gambaran umum perusahaan Pizza Hut Delivery tersebut.

Biaya Pemesanan adalah biaya untuk proses pemesanan. Biaya ini mencakup biaya dari persediaan, formulir, pemprosesan pesanan, pembelian, dukungan administrasi, dan seterusnya.

Biaya Penyimpanan (holding cost), biaya ini untuk menyimpan atau membawa persediaan dalam simpanan. Biaya penyimpanan merupakan biaya yang terkait dengan meyimpan atau "membawa" persediaan dalam waktu tertentu. Oleh karena itu, biaya penyimpanan juga mencakup biaya barang using dan biaya terkait dengan penyimpanan, seperti asuransi, karyawan tambahan serta pembayaran bunga. barang yang dijual. Dalam hubungannya dengan biaya penyimpanan, pada penerapan sistem Just In Time perusahaan menginginkan keuntungan yang maksimal yaitu dengan jalan efisiensi persediaan dengan cara bahwa perusahaan tidak menyimpan persediaan bahan baku di gudang. Sehingga perusahaan tidak mengeluarkan biaya untuk penyimpanan, maka biaya penyimpanan nol rupiah.

Biaya Pembelian (purchase cost), harga per unit apabila item dibeli dari pihak luar, atau biaya produksi per unit apabila diproduksi dalam perusahaan. Biaya per unit akan selalu menjadi bagian dari biaya item dalam persediaan. Untuk pembelian item dari luar, biaya per unit adalah harga beli ditambah biaya pengangkutan. Sedangkan untuk item yang diproduksi di dalam perusahaan, biaya 
per unit adalah termasuk biaya tenaga kerja, bahan baku dan biaya overhead pabrik (Yamit, 2000:9). Biaya kekurangan persediaan (shortage cost/ stock cost), biaya kekurangan persediaan adalah konsekuensi ekonomis atas kekurangan dari luar majupun dalam perusahaan (Yamit, 2000:9).

Pada Pizza Hut Delivery biaya kekurangan persediaan tidak dapat diidentifikasi dan tidak terdapat pencatatannya tersebut. Perusahaan Pizza Hut Delivery tidak pernah melakukan pencatatan khusus untuk kekurangan persediaan atau pesanan yang tidak terpenuhi. Bila diidentifikasi biaya kekurangan persediaan memiliki beberapa biaya antara lain biaya kesempatan yang timbul karena terhentinya proses produksi dan biaya kehilangan pelanggan. Peneliti menganalisis Pizza Hut Delivery tidak pernah mengalami terhentinya proses produksi, karena proses produksi yang terjadi pada Pizza Hut Delivery terjadi ketika konsumen melakukan pesanan untuk diproduksi Pizza Hut Delivery. Hal lain yang dianalisis peneliti dari Pizza Hut Delivery adalah bahwa Pizza Hut Delivery tidak mengalami biaya kehilangan pelanggan, karena pada Pizza Hut Delivery apabila pesanan tidak sampai dalam waktu 30 menit maka Pizza Hut Delivery memberikan voucher Pizza gratis untuk diberikan kepada konsumen tersebut.

Satu pertimbangan dari sistem Just In Time adalah bahwa tingkat persediaan yang lebih rendah atau bahkan tanpa ada persediaan akan membawa lebih banyak kekurangan persediaan. Perusahaan yang menerapkan Just In Time hanya berproduksi sesuai dengan kebutuhan, tepat saat barang jadi tersebut hendak dikonsumsi. Sebagai perbandingan perusahaan non Just In Time 
berproduksi untuk persediaan (stock), dimana system ini mengandalkan peramalan penjualan dimasa mendatang. Masalah akan timbul bila ternyata peramalan sering salah, sehingga peramalan penjualan tidak sesuai dengan penjualan aktual. Konsekuensinya perusahaan non Just In Time harus menanggung biaya persediaan yang tinggi bila penjualan tidak sesuai dengan perkiraan penjualan. Dalam prakteknya perusahaan yang menerapkan Just In Time masih belum dapat mencapai keadaan produksi atas dasar pesanan (product in order) yang sempurna. Perusahaan masih memiliki persediaan barang jadi meskipun hal ini ditekan sampai tingkat yang rendah, karena terkadang konsumen benar-benar menghendaki suatu produk secara spontan dan tidak bersedia menunggu selesainya proses produksi.

Analisis dilakukan dengan analisis deskriptif yaitu melakukan perolehan data yang sesuai dengan kriteria yang telah ditetapkan, yaitu data - data biaya persediaan, pembelian bahan baku, dan pemakaian bahan baku serta data biaya pemesanan dan data biaya penyimpanan. Langkah-langkah yang dilakukan dalam menganalisis biaya persediaan berdasarkan metode Just In Time adalah: (1). Harga beli masing-masing bahan baku, (2). Membuat daftar semua biaya persediaan, (3). Mengidentifikasi persediaan Pizza Hut Delivery. Dari analisis biaya persediaan tersebut, kemudian dibandingkan dengan teori-teori dari studi kepustakaan dan dapat ditarik kesimpulan dan sebagai langkah perbaikan diberikan beberapa saran yang sekiranya dapat dilakukan dan bermanfaat bagi perusahaan. 
El Bethree Jeremya Janson B. Penerapan Just In Time .....

\section{PEMBAHASAN}

Pizza Hut Delivery merupakan perusahaan dagang yang menjual pizza dengan rasa yang bervarian. Awal berdirinya Pizza Hut Delivery dilatar belakangi suksesnya merk Pizza Hut pada tahun 1984 di Indonesia, sehingga pada bulan Oktober tahun 2007 PT Sarimelati Kencana melakukan perluasan bidang usahanya yaitu mendirikan Pizza Hut Delivery. Pizza Hut Delivery pertama kali didirikan di Jakarta pada bulan Oktober tahun 2007. Pizza Hut Delivery dalam pemasarannya juga tidak lepas dari lifestyle masyarakat yang pada umumnya tinggal di perkotaan dengan kondisi kota yang macet, kesibukan di kantor, ataupun untuk merasakan kebersamaan keluarga di rumah.

Saat ini Pizza Hut Delivery sudah memiliki banyak outlet yang didirikan di kota-kota besar, seperti Jabodetabek, Bandung, Yogyakarta, Surabaya, Medan, Bali, dan masih banyak kota lainnya. Hal tersebut dilakukan Pizza Hut Delivery untuk memperluas ruang lingkup pemasarannya.

Manajemen persediaan sangat diperlukan untuk menjaga kelancaran proses produksi, begitu juga untuk perusahaan Pizza Hut Delivery. Selama proses produksi bahan baku sangat penting dan sangat dibutuhkan untuk proses produksi tersebut. Terdapat beberapa macam bahan baku yang kebutuhannya sangat signifikan digunakan Pizza Hut Delivery dalam proses produksinya, antara lain: Dough (adonan), keju mozzarella, dan sauce. 
Tabel 1.

Frekuensi Bahan Baku Pizza Hut Delivery Kerobokan Tahun 2016 dan 2017

\begin{tabular}{ccc}
\hline Bahan baku & Frekuensi Tradisional & Frekuensi JIT \\
\hline Dough & $48 \mathrm{kali}$ & $96 \mathrm{kali}$ \\
Keju Mozzarella & $48 \mathrm{kali}$ & $96 \mathrm{kali}$ \\
Sauce & $48 \mathrm{kali}$ & $96 \mathrm{kali}$ \\
\hline
\end{tabular}

Sumber: Pizza Hut Delivery Kerobokan, 2018

Dari Tabel 1 dapat diketahui untuk frekuensi pemesanan bahan baku menurut metode tradisional sebanyak 48 kali per tahun, sedangkan dengan menggunakan metode Just In Time sebanyak 96 kali. Frekuensi pembelian bahan baku dough, keju mozzarella, dan sauce yang biasanya dikirim pemasok satu bulan empat kali sehingga dalam satu tahun terjadi (48) kali frekuensi pengiriman pesanan, apabila frekuensi pembelian Just In Time perusahaan menginginkan frekuensi pemesanan bahan baku dalam satu bulan dilakukan delapan kali, maka perusahaan mengadakan kerja sama (kontrak) mengenai pengiriman tersebut dengan demikian frekuensi pengiriman bahan sistem Just In Time akan menjadi (96) kali dalam satu tahun.

Tabel 2.

Harga Bahan Baku Pizza Hut Delivery Kerobokan Tahun 2016 dan 2017

\begin{tabular}{cc}
\hline Bahan baku & Harga per Satuan \\
\hline Dough & $34.775 / \mathrm{Kg}$ \\
Keju Mozzarella & $120.000 / \mathrm{Kg}$ \\
Sauce & $108.500 / \mathrm{Kg}$ \\
\hline
\end{tabular}

Sumber: Pizza Hut Delivery Kerobokan, 2018

Dari Tabel 2, maka dapat diketahui harga bahan baku pada tahun 2016 dan tahun 2017. Untuk bahan baku dough dengan harga Rp 34.775/Kg, bahan baku keju mozzarella $\mathrm{Rp} 120.000 / \mathrm{Kg}$ dan bahan baku sauce dengan harga $\mathrm{Rp}$ $108.500 / \mathrm{Kg}$ 
Menurut Bapak Abbi selaku manajer area biaya pemesanan adalah biaya yang ditanggung oleh perusahaan akibat adanya pemesanan persediaan bahan baku. Biaya-biaya pemesanan tersebut mencakup tiga macam biaya, yaitu: biaya angkut, biaya telepon, dan biaya administrasi gudang. Biaya angkut yang dikeluarkan Pizza Hut Delivery Kerobokan pada tahun 2016 yaitu sebesar Rp 3.375.000, biaya telepon sebesar Rp 1.920.000, dan biaya administrasi gudang sebesar Rp 675.000. Tahun 2017 biaya angkut yang dikeluarkan Pizza Hut Delivery Kerobokan adalah sebesar $\mathrm{Rp}$ 3.893.700, biaya telepon sebesar $\mathrm{Rp}$ 2.150.000, dan biaya administasi gudang sebesar Rp 787.100.

Biaya penyimpanan dibebankan perusahaan berdasarkan persediaan ratarata. Pada tahun 2017, perusahaan memberikan persentase biaya penyimpanan untuk bahan baku dough, keju mozzarella, dan sauce sebesar 5\% dari nilai ratarata persediaan. Nilai rata-rata persediaan berasal dari kebutuhan bahan baku setiap bulan dikali dengan harga bahan baku dibagi dua. Biaya penyimpanan yang dikeluarkan Pizza Hut Delivery Kerobokan untuk menyimpan bahan baku dough, keju mozzarella, dan sauce pada tahun 2016 adalah sebesar Rp 321.513 .555 sedangkan biaya penyimpanan yang dikeluarkan Pizza Hut Delivery Kerobokan untuk menyimpan bahan baku dough, keju mozzarella, dan sauce pada tahun 2017 adalah sebesar Rp 270.160.749, dengan rincian biaya yang dapat dilihat pada lampiran 2.

Hasil analisis yang telah diuraikan, dapat diketahui gambaran keadaan Pizza Hut Delivery Kerobokan yang sesungguhnya terkait dengan penggunaan metode tradisional pada biaya persediaan bahan baku. Biaya persediaan bahan 
baku efisien dapat diperoleh dengan mengubah metode tradisional menjadi metode Just In Time. Biaya-biaya yang digunakan dalam metode Just In Time dalam penelitian ini adalah; 1). Biaya pemesanan, 2). Frekuensi pemesanan bahan baku, 3). Biaya penyimpanan.

Perusahaan menyadari dalam sistem Just In Time terdapat masalah dan perusahaan dapat mengatasinya dengan jalan antara lain dengan pesanan produksi yang sesuai dengan permintaan, mengadakan perjanjian kerja sama dengan pemasok baik jangka pendek maupun jangka panjang, dan perbaikan informasi. Pada tahun 2016 Pizza Hut Delivery Kerobokan memiliki biaya pemesanan secara tradisional bahan baku dough, keju mozzarella, dan sauce sebesar Rp 347.035.326, sedangkan pada tahun 2017 Pizza Hut Delivery Kerobokan memiliki biaya pemesanan secara Just In Time sebesar Rp 274.413.970.

Frekuensi pemesanan dalam sistem Just In Time lebih sering bila dibandingkan dengan pembelian secara tradisional. Pembelian dan pengiriman dapat dilakukan secara harian tergantung dari kebutuhan produksi perusahaan itu sendiri. Lokasi pemasok dalam konsep Just In Time biasanya berdekatan dengan lokasi pembeli, sehingga dapat memperlancar pengiriman barang pesanan. Terkadang pemasok harus menggunakan kendaraan pengangkut khusus yang didedikasikan hanya untuk satu perusahaan saja. Frekuensi pembelian Just In Time perusahaan menginginkan frekuensi pemesanan bahan baku dalam satu bulan dilakukan delapan kali sehingga frekuensi pengiriman bahan baku sistem Just In Time akan menjadi (96) kali dalam satu tahun. Perusahaan dalam 
pemesanan bahan baku, melakukan perjanjian atau kerja sama dengan pemasok sesuai dengan kriteria dan yang telah disepakati kedua belah pihak.

\section{Tabel 3.}

Frekuensi Pemesanan Sistem Tradisional dan Sistem Just In Time Pizza Hut Delivery Kerobokan Tahun 2016 dan 2017

\begin{tabular}{ccc}
\hline Bahan baku & Tradisional & Just In Time \\
& Tahun 2016 & Tahun 2017 \\
\hline Dough & 48 kali & 96 kali \\
Keju Mozzarella & 48 kali & 96 kali \\
Sauce & 48 kali & 96 kali \\
\hline
\end{tabular}

Sumber: Pizza Hut Delivery Kerobokan, 2018

Biaya penyimpanan pada penerapan sistem tradisional perusahaan dibebankan menanggung biaya penyimpanan yang jauh lebih tinggi karena pemesanan yang dilakukan empat kali sebulan dalam jumlah yang banyak. Perusahaan menginginkan keuntungan yang maksimal pada sistem Just In Time dengan jalan efisiensi persediaan dengan cara bahwa perusahaan tidak menyimpan persediaan bahan baku di Gudang, sehingga perusahaan tidak mengeluarkan biaya penyimpanan, maka biaya penyimpanan nol rupiah. Biaya penyimpanan pada tahun 2017 metode Just In Time perusahaan memberikan persentase biaya penyimpanan untuk bahan baku dough, keju mozzarella, dan sauce sebesar 5\% dari nilai rata-rata persediaan. Berdasarkan hasil perhitungan yang telah diuraikan, maka dapat dilihat pada lampiran 3 sistem biaya yang berkaitan dengan Just In Time dimana biaya penyimpanan sistem tradisional pada tahun 2016 sebesar Rp 160.756.778 sedangkan biaya penyimpanan sistem Just In Time sebesar Rp 135.080.575.

Dari hasil perhitungan mengenai biaya persediaan yang menggunakan sistem tradisional dan yang menggunakan sistem Just In Time terjadi perbedaan. Untuk lebih jelasnya dapat dilihat pada Tabel 4 sebagai berikut. 
Tabel 4.

Tabel Perbandingan Total Biaya Persediaan Antara Metode Tradisional pada tahun 2016 dan Metode Just In Time pada Tahun 2017

\begin{tabular}{cccc}
\hline Jenis Biaya Persediaan & $\begin{array}{c}\text { Tradisional } \\
(\mathrm{Rp})\end{array}$ & $\begin{array}{c}\text { Time } \\
\text { Tims }\end{array}$ & \multicolumn{1}{c}{$\begin{array}{c}\text { Efisiensi } \\
(\mathrm{Rp})\end{array}$} \\
\hline Biaya Pemesanan & 10.750 .436 & 6.704 .250 & 4.046 .186 \\
Biaya Pembelian & 385.514 .825 & 364.285 .021 & 21.229 .804 \\
& & & \\
Biaya Penyimpanan & 9.191 .035 & 7.363 .066 & 1.827 .969 \\
Total & 405.456 .296 & 378.352 .337 & 27.103 .959 \\
\hline Sumber: Pizza Hut Delivery Kerobokan, 2018 & &
\end{tabular}

Berdasarkan Tabel 4 maka dapat diketahui total biaya persediaan dengan sistem tradisional yang ada pada Pizza Hut Delivery Kerobokan pada tahun 2016 sebesar Rp. 405.456.296, sedangkan biaya persediaan dengan sistem Just In Time pada tahun 2017 sebesar Rp. 378.352.337. Sehingga ada efisiensi nilai biaya persediaan sebesar Rp. 27.103.959. Hal lain yang menyebabkan efisiensi biaya persediaan adalah adanya hubungan kontrak jangka panjang perusahaan Pizza Hut Delivery dengan pemasok yang dapat meminimalisir biaya pemesanan pada sistem Just In Time, sehingga dapat menimbulkan efisiensi biaya persediaan.

\section{SIMPULAN DAN SARAN}

Berdasarkan pembahasan yang telah dilakukan, maka dapat ditarik beberapa kesimpulan, yaitu: 1). Penerapan metode Just In Time pada perusahaan dapat meningkatkan efisiensi biaya persediaan. Pembelian dapat dilakukan dalam jumlah yang kecil dan pengiriman secara berkala, sehingga dapat menekan terjadinya biaya penyimpanan pada perusahaan; 2). Nilai biaya persediaan Pizza Hut Delivery Kerobokan pada tahun 2016 sesuai dengan hasil perhitungan tradisional sebesar Rp. 405.456.296, sedangkan dari hasil perhitungan Just In 
Time nilai biaya persediaan pada tahun 2017 sebesar Rp. 378.352.337, sehingga ada efisiensi nilai biaya persediaan sebesar Rp. 27.103.959

Berdasarkan kesimpulan yang penulis kemukakan diatas, maka ada beberapa saran yang diharapkan dapat berguna bagi perusahaan maupun pihak pihak lain. Pizza Hut Delivery Kerobokan dapat melakukan penurunan biaya (cost reduction) untuk mengefisienkan biaya persediaan dengan cara menerapkan sistem pembelian secara Just In Time. Kemudian perusahaan diharapkan dapat menghilangkan segala yang tidak memiliki nilai tambah dengan cara tidak menyimpan persediaan di gudang. Hal yang harus dilakukan adalah melakukan pembelian dalam jumlah kecil dan pengiriman secara berkala, sehingga terjadi efisiensi biaya persediaan. Serta mengadakan kesepakatan dengan pemasok mengenai kualitas, jumlah, dan waktu pengiriman bahan baku dengan adanya kesepakatan dengan pemasok perusahaan dapat meminimalisir biaya penyimpanan dan pemesanan.

\section{DAFTAR RUJUKAN}

Abduh, Muhammad., dan Elvi M Siahaan. (2007). Pengaruh Sistem Manajemen Persediaan Dengan Konsep Just In Time (JIT) Terhadap Pengendalian Biaya Persediaan. Jurnal Forum Ilmiah Indonusa, 4(2), hal.83-93.

Andhi Johan. (2008). Just In Time (JIT): Sebuah Panduan Menuju Keunggulan Kompetitif. Jurnal Pro Bisnis Universitas Wijayakusuma Purwokerto, 1(1), hal.1-9.

Assauri, Sofjan. (2008). Manajemen Produksi dan Operasi. Edisi Keempat. Jakarta: Lembaga Penerbit Fakultas Ekonomi Universitas Indonesia.

Beck, Fabian G., Grosse, Eric H., Teßmann Ruben. (2015). An Extention for Dynamic Lot-sizing Heuristics. Production and Manufacturing Research, 3(1), pp: 19-35. 
Blocher, Edward J., K. H Chen., T. W. Lin. (2002). Cost management: a strategic emphasis (2nd ed.). New York: McGraw-Hill.

Bon, Abdul Talib., dan Anny Garai. (2011). Just In Time Approach In Inventory Management. Faculty of Technology Management, Business and Entrepreneurship Universiti Tun Hussein Onn Malaysia, pp.1-9.

Chan, S. Yin dan F. T. S. Chan. (2010). Implementing Just In Time Philosophy to Reverse Logistics Systems: a review. International Journal of Production Research, 48(21), pp.6293-6313.

Chang, C. T., dan H. C. Chou. (2012). A coordination system for seasonal demand problems in the supply chain. Applied Mathematical Modelling, 37, pp.3674-3686.

Dalci, Ilhan., dan Veyis Naci Tanis. (2006). The Effect and Implementation of Just In Time System From A Cost and Management Accounting Perspective. Ç.Ü. Sosyal Bilimler Enstitüsü Dergisi, 15(1), pp.109-124.

Diaz, Andriany Pratiwi dan Endang Dwi Retnani. (2015). Penerapan Metode JIT Pembelian Bahan Baku Dalam Meningkatkan Efisiensi Biaya Bahan Baku. Jurnal Ilmu \& Riset Akuntansi, 4(10), hal.1-16.

Diaz dan Ardalan. (2009). An Analysis of Dual Kanban Just In Time Systems in a Non-Repetitive Environment. Production and Operations Management, 19(2), pp.233-245.

Farsijani, Hassan., Yasser Sobhani Fard., Maryam Akhavan Kharazian., Mohsen Shafiei Nikabadi. (2010). A Method for Identifying Critical Success Factors of JIT Implementation in Different Circumstances (Case Study: Appliance Industry). International Journal of Supply Chain Management Systems, pp.1-9.

Heineke, Davis. (2005). Operation Management Integrating Manufacturing \& Services, 5th ed. McGraw Hill International Edition.

Heizer, Jay dan Barry Render. (2016). Manajemen Operasi: Manajemen Keberlangsungan dan Rantai Pasokan, Edisi Kesebelas. Jakarta: Salemba Empat.

Heri Sukendar. (2011). Penerapan Just In Time dalam Sistem Pembelian dan Sistem Produksi. Binus Business Review, 2(1), hal.446-455.

Herjanto, Eddy. (2008). Manajemen Operasi, Edisi Ketiga. Jakarta: PT. Grasindo.

Hou, Bou., Hing Kai Chan, Xiaojun Wang. (2011). A Case Study of Just in Time System in the Chinese Automotive Industry. Proceedings of the World Congress on Engineering, 1, pp.1-5.

Imam, Kamarul. (2009). Manajemen Persediaan. Jember: Fakultas Ekonomi Universitas Jember. 
Jaya, Hendri. (2014). Analisis Pengaruh Sistem Just In Time Dalam Menunjang Kelancaran Proses Produksi: Studi Kasus Pada PT Siix Electronics Indonesia. Jurnal Measurement, 8(3), hal.25-33.

Kootanaee, Akbar Javadian., K Nagendra Babu., Hamidreza Fooladi Talari. (2013). Just In Time Manufacturing System: From Introduction to Implement. International Journal of Economics, Business and Finance, 1(2), pp.07-25.

Kumar, Vikas. (2010). JIT Based Quality Management: Concepts and Implications in Indian Context. International Journal of Engineering Science and Technology, 2(1), pp 40-50.

Madianto, Azhar., Dzulkirom AR., Dwiatmanto. (2016). Analisis Implementasi Sistem Just In Time (JIT) Pada Persediaan Bahan Baku Untuk Memenuhi Kebutuhan Produksi (Studi Pada PT Alinco, Karangploso, Malang). Jurnal Administrasi Bisnis (JAB), 38(1), hal.183-190.

Nurdin, Zul Hidayat., Sugiono., Ihwan Hamdala. (2015). Perencanaan Pengelolaan Persediaan Bahan Baku Penolong Rokok Sigaret Kretek Mesin Dengan Pendekatan Just In Time (Studi Kasus PT. Cakra Guna Cipta Malang) Jurnal Rekayasa Dan Manajemen Sistem Industri, 3(3), hal.443-452.

Ozalp, Inan., Bahar Suvaci, H. Zumrut Tonus. (2010). A New Approach In Logistics Management: Just In Time Logistics (JIT-L). International Journal of Business and Management Studies, 2(1), pp.37-45.

Pai, Rajesh R., Sunnith Hebbar., Giridhar Kamath. (2013). Improvement of Process Productivity through Just In Time. Research Journal of Management Sciences, 2(12), pp.1-6.

Panizzolo, R \& Garengo, P. (2013). Using Theory of Constraints to Control Manufacturing Systems: A Conceptual Model. Industrial Engineering and Management, 3(3), pp.2-9.

Phogat, Sandeep. (2013). Introduction to JIT: A Review. International Journal of Latest Research in Science and Technology, 6(2), pp.97-101.

Putra, Christyandhika. (2014). Penerapan Metode Just In Time untuk Meningkatkan Efisiensi Biaya Persedian Bahan Baku. Jurnal Ilmu \& Riset Akuntansi, 3(1), hal.1-20.

Sari, Heny Permata., Moch. Dzulkirom AR., Muhammad Saifi. (2014). Analisis Just In Time System Dalam Upaya Meningkatkan Efisiensi Biaya Produksi (Studi Kasus Pada PT. Malang Indah Genteng Rajawali Malang). Jurnal Administrasi Bisnis (JAB), 13(1), hal.1-10.

Serang, Serlin dan Surachman. (2012). Implementasi Just In Time dan Pengaruhnya Terhadap Kinerja Operasional dan Kinerja Perusahaan 
Manufaktur di Kota Makassar (Studi pada Kawasan Industri Makassar). Jurnal Aplikasi Manajemen, 10(4), hal.722-232.

Singh, Sultan Dr dan Garg, Dixit Dr. (2011). JIT System: Concepts, Benefits and Motivation in Indian Industries. International Journal of Management and Business Studies, 1(1), pp.26-30.

Tjahjadi. (2001). JIT Production Systems: Pengaruhnya Terhadap Kinerja Produktivitas, Majalah Ekonomi, (3), hal.226-238

Veselko, Gregor dan Igor Jakomin. (2006). Just In Time As A Logistical Supply Concept. Promet-Traffic\&Transportation, 18(4), pp.279-283.

$\mathrm{Xu}$, Yuchun., and $\mathrm{Mu}$ Chen. (2016). Improving Just In Time manufacturing operations by using Internet of Things based solutions. Procedia CIRP, 56, pp.326-331. 